\title{
A review of cosmetic contact lens infections
}

\author{
Chris H. L. Lim ${ }^{1,2}$ • Fiona Stapleton ${ }^{2}$ Jodhbir S. Mehta ${ }^{3,4}$
}

Received: 25 August 2018 / Revised: 3 October 2018 / Accepted: 5 October 2018 / Published online: 1 November 2018

(c) The Royal College of Ophthalmologists 2018

\begin{abstract}
This paper provides a comprehensive review of the existing literature surrounding cosmetic contact lens infections. In this paper, lens-related, dispensing-related and patient-related factors are examined in detail.
\end{abstract}

\section{Introduction}

Cosmetic contact lenses, although originally developed for patients with disfiguring abnormalities of the iris and cornea (Fig. 1), are also used by healthy individuals for cosmetic enhancement (Fig. 2) [1,2]. These lenses can either modify or augment the appearance of an individual's eye and are commonly referred to as circle, decorative or "big-eye" lenses [3,4]. Novelty lenses are also available and frequently used by patients for fancy dress events [5].

Cosmetic contact lens wearers make up a significant and growing proportion of the contact lens wearing population in Asian countries, such as Taiwan, Korea, Singapore, Malaysia, Thailand, Hong Kong and China, ranging from $24 \%$ in Taiwan to 39\% in Singapore of contact lens wearers surveyed $[6,7]$. The increased use of cosmetic lenses has been reported particularly, in young emmetropic individuals $[8,9]$. These lenses are often used by females, with industry-led surveys reporting up to 88 percent of women surveyed expressing an interest in changing the appearance of their eyes with coloured contact lenses [10].

Complications associated with the use of cosmetic contact lenses are similar to those associated with conventional contact lens use [11]. Of these, contact lens-related

Jodhbir S. Mehta

jodmehta@gmail.com

1 Department of Ophthalmology, National University Health System, Singapore, Singapore

2 School of Optometry and Vision Science, University of New South Wales, Sydney, NSW, Australia

3 Singapore National Eye Centre, Singapore, Singapore

4 Ophthalmology and Visual Sciences Academic Clinical Prog ram, Duke-NUS Graduate Medical School, Singapore, Singapore microbial keratitis represents the most feared complication. Microbial keratitis can be a visually devastating disease and is associated with significant personal and societal costs $[12,13]$. The incidence of disease has yet to be reported due to difficulties in estimating penetrance of wear within the community. However, a case control study has established that cosmetic contact lens wearers are at a 16.5 fold increased risk of infection compared with wearers of lenses used for refractive correction [14]. Cosmetic contact lens wearers made up $12.5 \%$ of corneal infections presenting to 12 university hospitals in France while also appearing to be overrepresented in a South Korean study, comprising $42.1 \%$ of cases presenting to 22 institutions and clinics [8].

This review aims to explore the lens, patient and dispensing-related factors that may contribute to the risk of microbial keratitis in cosmetic contact lens wearers (Table 1). We will also examine the microbiological characteristics of microbial keratitis associated with cosmetic contact lens wear.

\section{Lens-related Factors}

The production of cosmetic contact lenses involves a range of methods used to achieve realistic colouring effects [15]. These methods include dye dispersion tinting, vat-dye tinting, dye printing and chemical bond tinting techniques for translucent tints, while opaque tints may be achieved with dot-matrix printing, laminate, or opaque backing techniques (Fig. 3) [15]. These characteristics have been associated with visual disturbances, which may include visual field limitations, blurring of peripheral vision and increased higher-order aberrations resulting in a reduction in contrast sensitivity [16-20].

Exposed pigments on the surface of cosmetic contact lenses can predispose wearers to a host of complications 


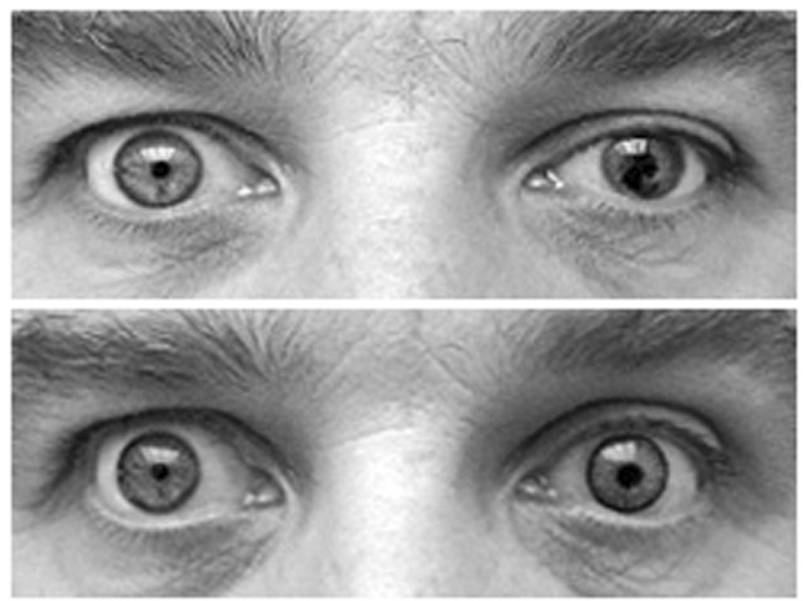

Fig. 1 Use of a prosthetic contact lens in a patient with an iris coloboma to achieve a more natural appearance. Images courtesy of Orion Vision Group
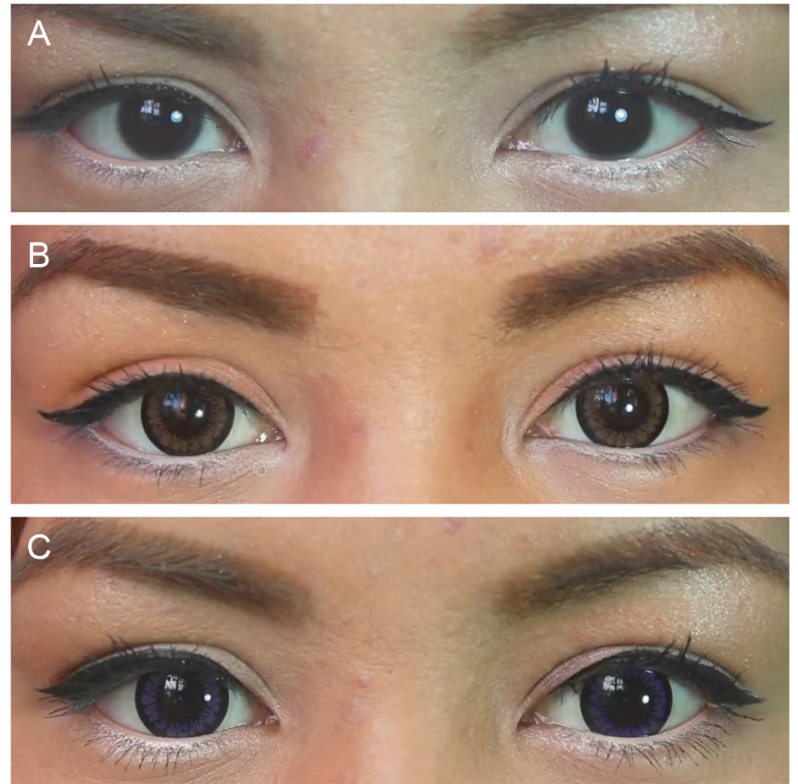

Fig. 2 Use of brown (b) and blue (c) cosmetic contact lenses to achieve a varied cosmetic effect in an individual. Panel (a) demonstrates the appearance prior to lens wear

[21-23]. Although specifics surrounding materials used to achieve these coloured effects are limited, chlorine, titanium and iron elements have been retrieved [22]. Dye pigments used in the manufacturing process may induce toxic reactions, with resultant corneal epithelial trauma and possible long-term implications on systemic health [22]. Systemic iron absorption for instance, may result in secondary hemochromatosis and immune mediated organ dysfunction secondary to cellular iron toxicity $[24,25]$. The use of cosmetic contact lenses during procedures, such as intense pulsed-light therapy, may also result in corneal deposition of pigments [21]. Laminate technologies have been developed as a more stable and safe method to generate coloured patterns. This method permits encapsulation of dyes and tints within layers of the lens polymer, thus limiting exposure of the ocular surface to these substances [15]. In a study performed by Chan et al., moistened cotton buds were used to apply a gentle rubbing force to the surface of cosmetic contact lenses [26]. Following which, the tip of this cotton bud was inspected for the presence of any pigments. Only 2 out of 15 brands of commercially available cosmetic contact lenses tested demonstrated permanency of pigments with a gentle rubbing force applied to the surface of lenses using moistened cotton buds [26]. Pigments were retrieved in 6 out of 8 of the included lenses where manufacturers had reported embedded or sandwich designs for their lenses. Lenses which failed this test further demonstrated higher levels of bacterial adherence [26]. A separate study performed on tinted contact lenses using a variety of imaging techniques including light microscopy, atom force microscopy, focused ion beam milling, scanning electron microscopy, and anterior segment fourier-domain optical coherence tomography did not identify disparities between reported manufacturing techniques and imaging findings [27]. These findings taken together would suggest there is considerable variability in manufacturing quality even within laminate designs.

In addition, increased surface roughness of cosmetic contact lenses compared to conventional contact lenses has also been demonstrated [27, 28]. The extent of this characteristic has been described to be dependent on the manufacturing technique applied, with no differences identified by Jung et al. in contact lenses where colourants were buried in contact lenses [27]. However, in contact lenses with surface pigment, a considerable difference was noted between the roughness of front and back surfaces [27]. The undulating lens surface and uneven application of pigments may not only be associated with discomfort, but can also result in mechanical trauma to the palpebral conjunctiva or corneal surface $[26,29,30]$. This has been suggested as a possible mechanism underlying bilateral diffuse lamellar keratitis following cosmetic contact lens wear in a postlaser-assisted in-situ keratomileusis patient [31]. Surface roughness may further decrease lens wettability and facilitate adherence and proliferation of microorganisms and protein deposits $[26,32,33]$. These factors may be relevant in the development of microbial keratitis.

Given the popularity of these lenses, counterfeit and unapproved cosmetic contact lenses (Fig. 4) have made their way into various supply routes worldwide [34, 35]. This is of concern, as the quality and safety of these products are not established. A significant proportion of unused counterfeit and unapproved decorative, non-corrective contact lenses tested by the United States Food and Drug Administration demonstrated microbial contamination with 


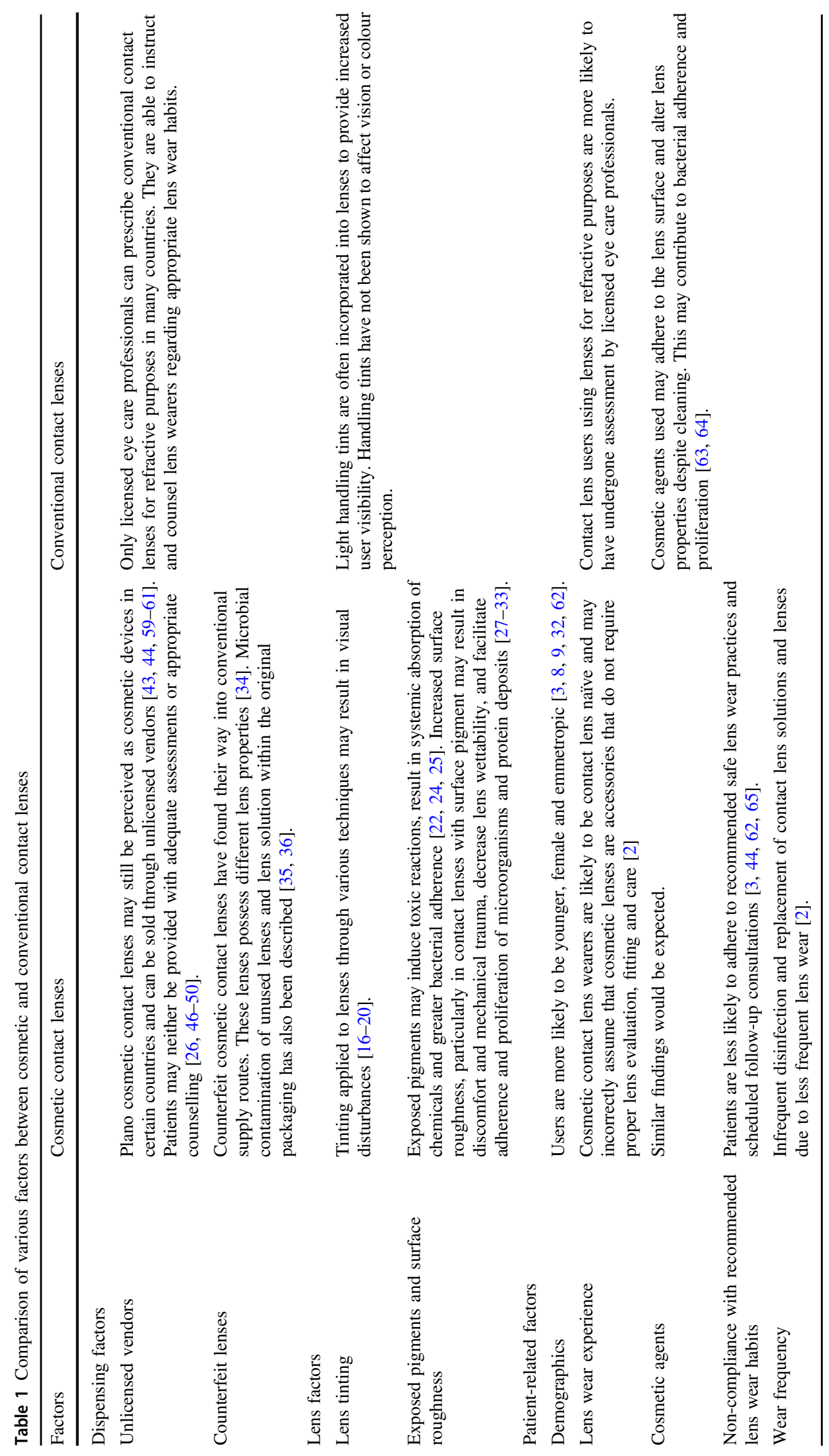




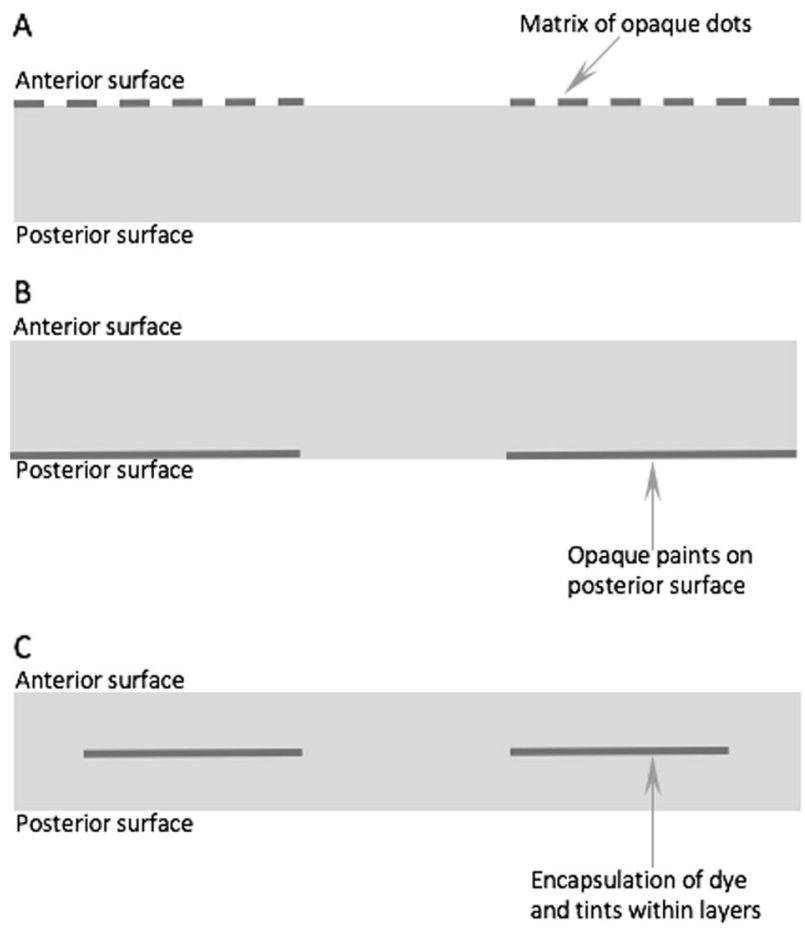

Fig. 3 An illustration of dot-matrix (a), opaque backing (b) or laminate construction (c) techniques to apply opaque tints to cosmetic contact lenses

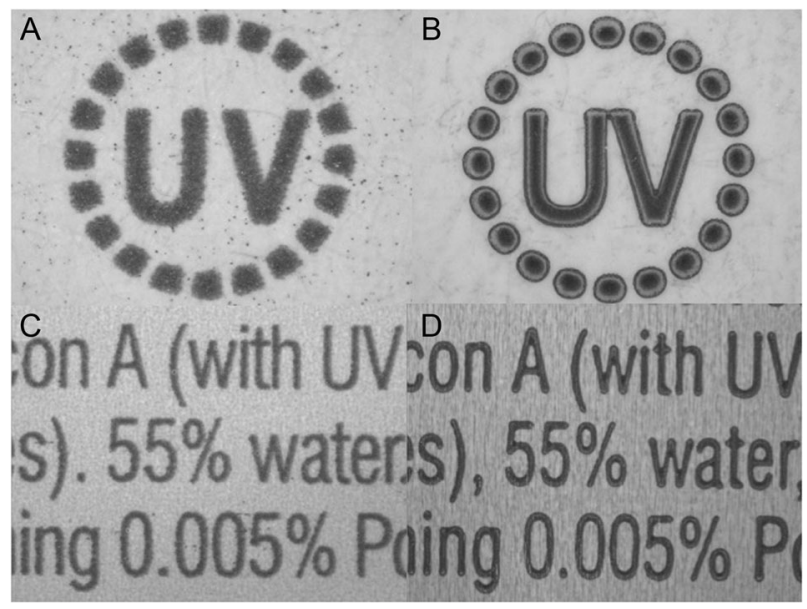

Fig. 4 Comparison in packaging between counterfeit $(\mathbf{a}, \mathbf{c})$ and authentic (b, d) and coloured contact lenses. Images courtesy of Health Sciences Authority Singapore

pathogenic organisms isolated from both the lenses and lens solution within the packaging $[35,36]$. These lenses have also been demonstrated to possess altered lens properties; including lower water content and increased lens thickness compared to the original products [36]. These findings increase the risks of developing complications such as hypoxic related complications, and contact lens-related discomfort and dryness.

Cosmetic contact lenses are also more likely to be worn occasionally compared to conventional lenses used for refractive correction [2]. These lenses may be stored in contact lens solutions for prolonged periods [2]. The lack of frequent disinfection and replacement of contact lens solutions decreases the antimicrobial efficacy of the solutions and may encourage microorganism adhesion, proliferation and possible formation of biofilms on both contact lenses and contact lens cases [37, 38]. The development of biofilms not only provides potential areas of attachments for microorganisms, but also protects bacteria from disinfectants [39-41]. These factors may contribute to a higher bacterial load inoculated on the ocular surface and increase retention time, which in-turn increases the risks of developing microbial keratitis [42].

\section{Dispensing-related Factors}

Challenges exist in the regulation of cosmetic contact lenses [2]. Regulation of the supply and distribution of medical devices is important in ensuring their quality and safety [35]. Plano cosmetic contact lenses were, until recent times, perceived as novelty items or cosmetic devices [43]. Their sale through unlicensed vendors such as flea markets and street-side stalls, video stores, hair salons and gas stations, in addition to internet retailers has been documented [44]. These lenses are often sold in colourful, eye-catching packaging to appeal to a younger audience [3]. However, increased exposure to these products may result in an increased number of infections [32].

The internet offers an attractive method of retailing products, as transactions are completed virtually without a need for consumers to be physically present. This also obviates the need for a physical store, hence reduces overheads, which increases profit margins and reduces costs passed on to consumers. However, internet purchase of contact lenses is an independent risk factor in the development of microbial keratitis [45].

Wearers purchasing contact lenses from these supply routes are often not adequately assessed, counselled or instructed on safe contact lens wear practices or potential complications [26, 46-50].. These users are also less likely to be compliant with safe lens wear practices [51]. A survey of medical students who were contact lens wearers demonstrated that only $2 \%$ of respondents were adequately counselled about complications associated with contact lens wear [52].

In response to increasing reports of complications, cosmetic contact lenses were reclassified as medical 
devices by the Food and Drug Administration in the United States [53]. A warning was issued against the use of such lenses without proper fitting and counselling in 2006 [53]. Unlicensed imports were also seized, whilst warnings were issued regarding improper marketing and distribution of such lenses by distributors. While many non-licensed distributors voluntarily withdrew products, contact lens manufacturers have also been actively assisting the regulation of this industry. For instance, CIBA Vision sent cease-and-desist letters to multiple vendors in the United States distributing cosmetic lenses illegally, and proceeded with legal action against recalcitrant companies [54].

Cosmetic contact lenses have since been gradually classified as medical devices in countries such as Malaysia, China and Korea [26, 55-57]. Supply of contact lenses to wearers has also been restricted to licensed eye care professionals in countries such as Singapore [58]. While efforts have been made by various authorities to educate and prosecute offenders, regulation of this industry remains tenuous and unlicensed vendors are often able to circumvent existing regulations to reach out to potential customers without provision of prerequisite professional advice or supervision through internet and makeshift stalls [59-61]. Counterfeit cosmetic contact lenses are also sold through conventional supply routes such as optical shops, with licensed merchants purchasing these lenses through third parties at reduced cost [34].

\section{Patient-related factors}

These problems are further exacerbated by the demographics of the population likely to utilise cosmetic contact lenses. Cosmetic contact lens wearers are more likely to be young, female, emmetropic and contact lens naïve $[3,8,9,32,62]$.

Up to $6 \%$ of contact lens wearers surveyed in Hong Kong were emmetropes, who were likely to be cosmetic contact lens wearers, while $15 \%$ of asymptomatic cosmetic contact lens wearers surveyed in Thailand were emmetropes [3, 9]. Emmetropic cosmetic contact lens wearers may perceive lenses as cosmetic accessories and incorrectly assume that proper lens evaluation, fitting and care is not required [2]. Cosmetic and novelty lenses may be more commonly used in conjunction with cosmetics for attendance at events. It has been demonstrated that cosmetic agents such as hand creams, make-up removers and mascara may adhere to the lens surface and alter lens properties despite subsequent cleaning [63, 64]. This may further contribute to bacterial adherence and proliferation. In a Korean survey of contact lens- related complications, $62.2 \%$ of patients who presented with cosmetic contact lens complications were emmetropic individuals [8].

Steinmann et al. have reported that up to $50 \%$ of all decorative lens wearers are first-time contact lens wearers, while Abbouda et al. who examined the attitude and practice of teenage contact lens wearers have suggested that younger contact lens wearers do not adequately comply with contact lens care practices and are less likely to be involved in their own care $[44,65]$. For instance, in a study by Mahittiokorn et al., $42 \%$ of cosmetic contact lens wearers reported considering using lenses that had fallen on the floor without prior cleaning or rinsing [3]. Patients presenting with cosmetic contact lenses related microbial keratitis are typically younger and less experienced contact lens wearers [32]. This group of patients who presented to healthcare institutions with cosmetic contact lens-related complications were also less likely to adhere to scheduled follow-up consultations compared to counterparts wearing conventional contact lenses [62]. The findings by Abbouda et al, mirror findings of the Contact Lens Assessment in Youth (CLAY) study, which has demonstrated the greatest risk of developing corneal infiltrates in patients was between the age of 15-25 [65, 66]. It was further found that patients younger than 15 years of age were more compliant with recommended lens wear habits [66].

Multiple studies have demonstrated high rates of noncompliance amongst conventional contact lens wearers [8, 67-70]. Even when lenses are dispensed by eye care professionals, large proportions of patients are noncompliant with safe lens wear practices $[8,67,69,70]$. A study surveying 500 healthcare workers in Pakistan further corroborated these results [68]. This is likely to be worse in the cosmetic contact lens population. Cosmetic contact lens wearers have been reported to delay presenting to an eye care specialist compared to conventional contact lens wearers, which has been identified as a risk factor for poorer visual outcomes [13, 32, 46, 71]. As a greater proportion of cosmetic contact lens wearers purchase lenses from non-conventional and unregulated routes, these individuals are less likely to have received adequate contact lens safety advice and may not be connected to eye care providers, which can contribute to their delayed presentation for treatment [46, 71]. A study by Singh et al. found that all 13 patients in their case series who developed microbial keratitis from cosmetic contact lens wear, were from lower socioeconomic classes [2]. While this has not been confirmed in an epidemiological study, conceivably this factor may act as a barrier to accessing healthcare and contribute to delayed presentations with resultant increased disease severity. 


\section{Causative organisms}

A range of pathogens have been implicated in the development of contact lens-related microbial keratitis. Bacterial keratitis typically predominates in temperate climates, while rates of fungal keratitis make up a larger proportion of microorganisms in tropical regions [72, 73]. It has been suggested that severe contact lens-related microbial keratitis is more likely to occur in warmer, humid weather compared to cooler conditions [74-76]. Commonly implicated bacteria include Pseudomonas, Staphylococcus and Streptococcus spp [2, 44, 70, 77-82]. Pseudomonas aeruginosa is the most common species, accounting for up to $60 \%$ of culture proven infections in contact lens wearers. Pseudomonas spp. was the most commonly isolated organism in a series of cosmetic contact lens wearers with microbial keratitis reported in India, Malaysia, Hong Kong, Australia and New Zealand [2, 79, 80, 83].

Microorganisms use a variety of techniques to increase their adherence and virulence $[38,84]$. Bacteria have been shown to possess varied ability to adhere to various contact lens materials and grow on tear film components adsorbed on the surface of worn lenses [39] Other mechanisms include formation of biofilms on either contact lenses or lenses by microorganisms such as Pseudomonas aeruginosa, Staphylococcus aureus, and Elizabethkingia species [29, 39, 42, 84].

In patients with contact lens-related fungal keratitis, Fusarium, Aspergillus and less frequently Candida spp. have been reported [80]. These organisms are of greater significance in subtropical and tropical climate, such as in the south-eastern Asian region.

Of significance, Acanthamoeba keratitis is a challenging condition to treat and has been increasingly reported in recent years, with case reports from the United States, New Zealand and Korea identifying cases of Acanthamoeba keratitis related to the use of cosmetic contact lenses [46, 85-87]. It has been suggested in a multicentre survey in the United Kingdom that up to $93 \%$ of patients presenting with a diagnosis of Acanthamoeba keratitis are contact lens wearers [88]. A more recent survey demonstrated similar findings, with $93.5 \%$ of patients presenting with Acanthamoeba keratitis reporting contact lens wear [89]. In these individuals, domestic water sources and subsequent contamination of contact lenses and associated lens care products have been identified as possible sources of contamination [90]. Kilvington et al. using mtDNA testing confirmed identical isolates recovered from the cornea and bathroom tap water in six out of eight contact lens wearers with Acanthamoeba keratitis [90]. In Korea, $4.2 \%$ of contact lens storage cases and $7.7 \%$ of domestic tap water samples recovered Acanthamoeba [91, 92]. A study involving Scottish patients with Acanthamoeba keratitis demonstrated higher rates of recovery (54 vs. $31 \%$ ) of Acanthamoeba in their home water supply compared to healthy contact lens wearing controls [93]. A larger proportion of cases were also identified to have used tap water in their contact lens care regime compared to controls, including the use of tap water for rinsing lens storage cases (79 vs $43 \%$ ) or contact lenses (21 vs $13 \%$ ) [93]. A study from Thailand by Mahittikorn et al. also demonstrated retrieval of Acanthamoeba-like trophozoites from $2 \%$ of cosmetic contact lenses obtained from healthy volunteers [3]. However, the contamination rates of domestic water sources reported in Asia are still comparatively lower compared to studies performed in other parts of the world.

\section{Recommendations}

This is a challenging situation requiring greater oversight of the licensing, manufacturing and distribution of cosmetic contact lenses. The main difficulty however is the unregistered manufacture, distribution and sale of these products. The discrepancies between manufacturing claims of laminated construction techniques and reported findings of pigments on lens surfaces are of concern [26]. Reporting channels for complications associated with cosmetic contact lenses to regulatory authorities should also be established and promoted amongst eye care and health professionals, while recognising that these practitioners are generally not part of the supply chain and may not see these wearers until they present with a problem. Other potential aspects include establishment of a regional registry to assist with information sharing and tracking of unlicensed vendors.

While a number of case reports have identified risks associated with these products, the size of the problem is still unknown. The magnitude of the population wearing these lenses in the community remains unclear due to the presence of non-traditional supply routes. Population based studies may allow estimates of incidence rates and potential risk factors [94]. This may in turn help to guide informed strategies to limit the risk associated with these products.

\section{Compliance with ethical standards}

Conflict of interest The authors declare that they have no conflict of interest.

\section{References}

1. Abdelkader A. Cosmetic soft contact lens associated ulcerative keratitis in southern Saudi Arabia. Middle East Afr J Ophthalmol. 2014;21:232. 
2. Singh S, Satani D, Patel A, Vhankade R. Colored cosmetic contact lenses: an unsafe trend in the younger generation. Cornea. 2012;31:777-9.

3. Mahittikorn A, Kittichathanakul T, To-Im J, Nacapunchai D. Knowledge, behavior, and free-living amoebae contamination of cosmetic contact lens among university wearers in Thailand: a cross-sectional study. Eye Contact Lens. 2017;43:81-88.

4. Park SH, Kim SR, Park M. The effect of circle lens and soft contact lens with identical material in clinical application on the eyes. J Opt Soc Korea. 2011;16:147-57.

5. Cassel M. Colored contact lens update. Contact Lens Spect. 2002;31:32-4.

6. Multi-sponsor Surveys International LLC. The 2010 Study of the International Contact Lens Market 2010. http://multisponsorinterna tional.com/wp-content/uploads/2012/10/10503-InternationalContact-Lens-Market.pdf.

7. Contact lens market in Asia booming. Singapore Press Holdings Digital News. http://www.asiaone.com/health/contact-lens-ma rket-asia-booming. Accessed 9 July 2018.

8. Kim JH, Song JS, Hyon JY, Chung SK, Kim TJ. A survey of contact lens-related complications in Korea: the Korean Contact Lens StudySociety. J Korean Ophthalmol Soc. 2014;55:20-31.

9. Charm J, Cheung SW, Cho P. Practitioners' analysis of contact lens practice in Hong Kong. Cont Lens Anterior Eye. 2010;33:104-11.

10. Joseph T, Barr LS, Color your contact lens practice. Contact Lens Spect. 2003. https://www.clspectrum.com/issues/2003/july-2003/ color-your-contact-lens-practice.

11. Lim CH, Stapleton F, Mehta JS. Review of contact lens-related complications. Eye Contact Lens 2018. Epub ahead of print. https://doi.org/10.1097/ICL.0000000000000481

12. Keay L, Edwards K, Naduvilath T, Taylor HR, Snibson GR, Forde K, et al. Microbial keratitis: predisposing factors and morbidity. Ophthalmology. 2006;113:109-16.

13. Keay L, Edwards K, Naduvilath T, Forde K, Stapleton F. Factors affecting the morbidity of contact lens-related microbial keratitis: A population study. Invest Ophthalmol Vis Sci. 2006;47:4302-8.

14. Bourcier T, Sauer A. Cosmetic contact lenses related microbial keratitis as a foreseeable disaster: a prospective study. Invest Ophthalmol Vis Sci. 2010;51:2884-2884.

15. Efron N. Contact lens practice. 3 ed. Elsevier, Netherlands 2017.

16. Ortiz C, Jiménez R. Optical quality and vision with iris-coloring soft contact lenses. Optom Vis Sci. 2014;91:564-9.

17. Spraul CW, Roth HJ, Gäckle H, Lang GE, Lang GK. Influence of special-effect contact lenses (Crazy Lenses) on visual function. CLAO J. 1998;24:29-32.

18. Gauthier C, Grant T, Holden B. Clinical performance of two opaque, tinted soft contact lenses. J Am Optom Assoc. 1992;63:344-9.

19. Diego CA, Montes-Mico R, Pons A, Artigas J. Influence of the luminance level on visual performance with a disposable soft cosmetic tinted contact lens. Ophthalmic Physiol Opt. 2001;21:411-9.

20. Özkagnici A, Zengin N, Kamis Ü, Gündüz K. Do daily wear opaquely tinted hydrogel soft contact lenses affect contrast sensitivity function at one meter? Eye Contact Lens. 2003;29:48-49.

21. Hong S, Lee JR, Lim T. Pigment deposition of cosmetic contact lenses on the cornea after intense pulsed-light treatment. Korean J Ophthalmol. 2010;24:367-70.

22. Hotta F, Eguchi H, Imai S, Miyamoto T, Mitamura-Aizawa S, Mitamura Y. Scanning electron microscopy findings with energydispersive $\mathrm{X}$-ray investigations of cosmetically tinted contact lenses. Eye Contact Lens. 2015;41:291.

23. Stergiopoulou T, Meletiadis J, Sein T, Papaioannidou P, Tsiouris I, Roilides E, et al. Isobolographic analysis of pharmacodynamic interactions between antifungal agents and ciprofloxacin against
Candida albicans and Aspergillus fumigatus. Antimicrob Agents Chemother. 2008;52:2196-204.

24. Walker EM, Walker SM. Effects of iron overload on the immune system. Ann Clin Lab Sci. 2000;30:354-65.

25. Eaton JW, Qian M. Molecular bases of cellular iron toxicity 12. Free Radic Biol Med. 2002;32:833-40.

26. Chan KY, Cho P, Boost M. Microbial adherence to cosmetic contact lenses. Cont Lens Anterior Eye. 2014;37:267-72.

27. Jung JW, Han SH, ah Kim S, Kim EK, Seo KY. Evaluation of pigment location in tinted soft contact lenses. Cont Lens Anterior Eye 2016;39:210-6.

28. Ji YW, Cho YJ, Lee CH, Hong SH, Chung DY, Kim EK, et al. Comparison of surface roughness and bacterial adhesion between cosmetic contact lenses and conventional contact lenses. Eye Contact Lens. 2015;41:25-33.

29. Szczotka-Flynn L, Lass JH, Sethi A, Debanne S, Benetz BA, Albright M, et al. Risk factors for corneal infiltrative events during continuous wear of silicone hydrogel contact lenses. Invest Ophthalmol Vis Sci. 2010;51:5421-30.

30. Steffen RB, Barr JT. Clear versus opaque soft contact lenses: initial comfort comparison. Int Contact Lens Clin. 1993;20: 184-6.

31. Chung MS, Pepose JS, Al-Agha S, Cavanagh HD. Confocal microscopic findings in a case of delayed-onset bilateral diffuse lamellar keratitis after laser in situ keratomileusis. J Cataract Refract Surg. 2002;28:1467-70.

32. Sauer A, Bourcier T. Keratitis FSGfCLRM. Microbial keratitis as a foreseeable complication of cosmetic contact lenses: a prospective study. Acta Ophthalmol. 2011;89:e439-42.

33. Butrus SI, Klotz SA. Contact lens surface deposits increase the adhesion of Pseudomonas aeruginosa. Curr Eye Res. 1990;9:717-24.

34. Health Sciences Authority. HSA alerts public to counterfeit coloured contact lenses sold in local optical shops. Available at: http://www.hsa.gov.sg/content/hsa/en/News_Events/Press_Relea ses/2011/hsa_alerts_public3.html. Accessed 8 August 2018.

35. Land AD, Penno KL, Brzezinski JL. Identification of microorganisms isolated from counterfeit and unapproved decorative contact lenses. J Forensic Sci. 2018;63:635-9.

36. Health Sciences Authority. Counterfeit coloured contact lenses sold in Singapore. Available at: http://www.hsa.gov.sg/content/ hsa/en/Health_Products_Regulation/Safety_Information_and_ Product_Recalls/Product_Safety_Alerts/2011/counterfeit_ coloured.html. Accessed 8 August 2018.

37. Marshall K, Stout R, Mitchell R. Mechanism of the initial events in the sorption of marine bacteria to surfaces. Microbiology. 1971;68:337-48.

38. Dutta D, Cole N, Willcox M. Factors influencing bacterial adhesion to contact lenses. Mol Vis. 2012;18:14.

39. Willcox M, Harmis N, Cowell B, Williams T, Holden B. Bacterial interactions with contact lenses; effects of lens material, lens wear and microbial physiology. Biomaterials. 2001;22:3235-47.

40. Lechevallier MW, Cawthon CD, Lee RG. Inactivation of biofilm bacteria. Appl Environ Microbiol. 1988;54:2492-9.

41. Szczotka-Flynn LB, Imamura Y, Chandra J, Yu C, Mukherjee PK, Pearlman E, et al. Increased resistance of contact lens related bacterial biofilms to antimicrobial activity of soft contact lens care solutions. Cornea. 2009;28:918.

42. McLaughlin-Borlace L, Stapleton F, Matheson M, Dart J. Bacterial biofilm on contact lenses and lens storage cases in wearers with microbial keratitis. J Appl Microbiol. 1998;84:827-38.

43. Sindt C. Cosmetic or decorative contact lenses. Contact Lens Update. 2014.

44. Steinemann TL, Pinninti U, Szczotka LB, Eiferman RA, Price Jr FW. Ocular complications associated with the use of cosmetic contact lenses from unlicensed vendors. Eye \& Contact Lens. 2003;29:196-200. 
45. Stapleton F, Keay L, Edwards K, Naduvilath T, Dart JK, Brian G, et al. The incidence of contact lens-related microbial keratitis in Australia. Ophthalmology. 2008;115:1655-62.

46. McKelvie J, Patel D, McGhee C. Cosmetic contact lens-related Acanthamoeba keratitis. Clin Exp Ophthalmol. 2009;37:419-20.

47. Park SJ, Lee SM, Kim MK, Han YK, Wee WR, Lee JH. Cosmetic contact lens-related complications: 9 cases. J Korean Ophthalmol Soc. 2009;50:927-35.

48. Connell B, Tullo A, Morgan P, Armstrong M. Pseudomonas aeruginosa microbial keratitis secondary to cosmetic coloured contact lens wear. Br J Ophthalmol. 2004;88:1603-4.

49. Sankaridurg P, Willcox M, Sharma S, Gopinathan U, Janakiraman D, Hickson S, et al. Haemophilus influenzae adherent to contact lenses associated with production of acute ocular inflammation. $\mathbf{J}$ Clin Microbiol. 1996;34:2426-31. http://contactlensupdate.com/ 2014/07/15/cosmetic-or-decorative-contact-lenses/.

50. Tseng SS-Y, Yang WW-C, Hsiao JC-J. Bilateral corneal erosion due to retail purchase of unfitted prescription contact lenses: a case report. Cornea. 2008;27:1179-81.

51. Fogel J, Zidile C. Contact lenses purchased over the Internet place individuals potentially at risk for harmful eye care practices. Optometry. 2008;79:23-35.

52. Roberts A, Kaye A, Kaye R, Tu K, Kaye S. Informed consent and medical devices: the case of the contact lens. Br J Ophthalmol. 2005;89:782-3.

53. U.S. Food \& Drug Administration. United States Food \& Drug Administration Guidance for industry. FDA staff, eye care professionals, and consumers: decorative, non-corrective contact lenses. Washington, DC: U.S. Food \& Drug Administration; 2006. Available at: https://www.fda.gov/downloads/Medica 1Devices/DeviceRegulationandGuidance/GuidanceDocuments/ ucm071578.pdf. Accessed 8 August 2018.

54. Garvey M. Health concerns tinge use of cosmetic lenses. Los Angeles Times (26 August 2002). 2002.

55. China Food and Drug Administration. SFDA specifies requirements for the supervision of decorative plano colored contact lenses. Vol. 66. China Food and Drug Administration. 2012. Available at: http://eng.sfda.gov.cn/WS03/CL0757/69552. html. Accessed on 8 August 2018.

56. Ministry of Health Singapore. Optometrists and opticians act. Singapore: Ministry of Health Singapore. Ch 213A; AttorneyGeneral's Chambers, 2008.

57. Sathasivam S. Medical device (declaration) o rder 2017. Malaysia. Malaysia: Attorney General's Chambers of Malaysia; 2017.

58. Ministry of Health Singapore. Legislative division. In: Optometrists and Opticians Act. Ch. 231A. Singapore: Attorney General's Chambers; 2007.

59. Ministry of Health Singapore. Cosmetic Contact Lenses. 2009. Available at: https://www.moh.gov.sg/content/moh_web/ home/pressRoom/Parliamentary_QA/2009/Cosmetic_Contact_ Lenses.html. Accessed 9 July 2018.

60. Chu MM. Cheap contact lens from pasar malam and online shops could make you go blind. SAYS, 2015. Available at: http://says. com/my/news/cheap-contact-lens-from-pasar-malam-and-onlineshops-could-make-you-go-blind. Accessed 9 July 2018.

61. Office of Public Affairs. Owner of major online colored contact lens business pleads guilty in largest-ever investigation of counterfeit and misbranded contact lenses in the United States. Nevada, USA: Department of Justice, United States of America; 2016.

62. Choi HJ, Yum JH, Lee JH, Lee DH, Kim JH. Clinical features and compliance in patients with cosmetic contact lens-related complications. J Korean Ophthalmol Soc. 2014;55:1445-51.

63. Luensmann D, Srinivasan $S$ The impact of eye cosmetics on contact lens wear: Lab-based research results. http://contactlensupdate.com/ 2014/12/17/the-impact-of-eye-cosmetics-on-contact-lens-wear-labbased-research-results/. Accessed 9 July 2018.
64. Srinivasan S, Otchere H, Yu M, Yang J, Luensmann D, Jones L. Impact of cosmetics on the surface properties of silicone hydrogel contact lenses. Eye Contact Lens. 2015;41:228-35.

65. Abbouda A, Restivo L, Bruscolini A, Pirraglia MP, De Marco F, La Cava M, et al. Contact lens care among teenage students in Italy: A cross-sectional study. Semin Ophthalmol. 2016;31: 226-32.

66. Chalmers RL, Wagner H, Mitchell GL, Lam DY, Kinoshita BT, Jansen ME, et al. Age and other risk factors for corneal infiltrative and inflammatory events in young soft contact lens wearers from the Contact Lens Assessment in Youth (CLAY) study. Invest Ophthalmol Vis Sci. 2011;52:6690-6.

67. Dumbleton K, Woods C, Jones L, Richter D, Fonn D. Comfort and vision with silicone hydrogel lenses: effect of compliance. Optom Vis Sci. 2010;87:421-5.

68. Khan MH, Mubeen SM, Chaudhry TA, Khan SA. Contact lens use and its compliance for care among healthcare workers in Pakistan. Indian J Ophthalmol. 2013;61:334.

69. Ky W, Scherick K, Stenson S. Clinical survey of lens care in contact lens patients. CLAO J. 1998;24:216-9.

70. van Zyl L, Cook C. Bacterial keratitis and corneal scarring secondary to cosmetic contact lens wear. S Afr Med J. 2010;100: 37-8.

71. Young G, Young AG, Lakkis C. Review of complications associated with contact lenses from unregulated sources of supply. Eye Contact Lens. 2014;40:58-64.

72. Liesegang TJ, Forster RK. Spectrum of microbial keratitis in South Florida. Am J Ophthalmol. 1980;90:38-47.

73. Leck A, Thomas P, Hagan M, Kaliamurthy J, Ackuaku E, John M, et al. Aetiology of suppurative corneal ulcers in Ghana and south India, and epidemiology of fungal keratitis. $\mathrm{Br} \mathrm{J}$ Ophthalmol. 2002;86:1211-5.

74. Stapleton F, Keay LJ, Sanfilippo PG, Katiyar S, Edwards KP, Naduvilath T. Relationship between climate, disease severity, and causative organism for contact lens-associated microbial keratitis in Australia. Am J Ophthalmol. 2007;144:690-8. e691.

75. Hoddenbach JG, Boekhoorn SS, Wubbels R, Vreugdenhil W, Van Rooij J, Geerards AJ. Clinical presentation and morbidity of contact lens-associated microbial keratitis: a retrospective study. Graefes Arch Clin Exp Ophthalmol. 2014;252: 299-306.

76. Green M, Apel A, Stapleton F. A longitudinal study of trends in keratitis in Australia. Cornea. 2008;27:33-39.

77. Larkin D, Leeming J. Quantitative alterations of the commensal eye bacteria in contact lens wear. Eye. 1991;5:70.

78. Fong C-F, Hu F-R, Tseng C-H, Wang I-J, Chen W-L, Hou Y-C. Antibiotic susceptibility of bacterial isolates from bacterial keratitis cases in a university hospital in Taiwan. Am J Ophthalmol. 2007; 144:682-9.

79. Houang E, Lam D, Fan D, Seal D. Microbial keratitis in Hong Kong: relationship to climate, environment and contact-lens disinfection. Trans R Soc Trop Med Hyg. 2001;95:361-7.

80. Norina T, Raihan S, Bakiah S, Ezanee M, Liza-Sharmini A, Wan Hazzabah W. Microbial keratitis: aetiological diagnosis and clinical features in patients admitted to Hospital Universiti Sains Malaysia. Singap Med J. 2008;49:67-71.

81. Lim C, Carnt N, Farook M, Lam J, Tan D, Mehta J, et al. Risk factors for contact lens-related microbial keratitis in Singapore. Eye. 2016;30:447.

82. Hovding G. The conjunctival and contact lens bacterial flora during lens wear. Acta Ophthalmol. 1981;59:387-401.

83. Stapleton F, Alves M, Bunya VY, Jalbert I, Lekhanont K, Malet F, et al. TFOS DEWS II Epidemiology Report. Ocul Surf. 2017;15:334-65.

84. Kodjikian L, Casoli-Bergeron E, Malet F, Janin-Manificat H, Freney $\mathrm{J}$, Burillon $\mathrm{C}$, et al. Bacterial adhesion to conventional 
hydrogel and new silicone-hydrogel contact lens materials. Graefes Arch Clin Exp Ophthalmol. 2008;246:267-73.

85. Kerr NM, Ormonde S. Acanthamoeba keratitis associated with cosmetic contact lens wear. N Z Med J. 2008;121: 1286.

86. Lee JS, Hahn TW, Choi SH, Yu HS, Lee JE. Acanthamoeba keratitis related to cosmetic contact lenses. Clin Exp Ophthalmol. 2007;35:775-7.

87. Snyder RW, Brenner MB, Wiley L, Yee RW, Gradus MS, Mackman GS. Microbial keratitis associated with plano tinted contact lenses. CLAO J. 1991;17:252-5.

88. Radford CF, Lehmann OJ, Dart JK. Acanthamoeba keratitis: multicentre survey in England 1992-6. $\mathrm{Br} \mathrm{J}$ Ophthalmol. 1998;82:1387-92.

89. Carnt N, Robaei D, Minnasian D, Dart J. Presentation and outcomes of acanthamoeba keratitis at moorfields eye Hospital, 1991-2012. Cont Lens Anterior Eye. 2015;38:e35.
90. Kilvington S, Gray T, Dart J, Morlet N, Beeching JR, Frazer DG, et al. Acanthamoeba keratitis: the role of domestic tap water contamination in the United Kingdom. Invest Ophthalmol Vis Sci. 2004;45:165-9.

91. Jeong HJ, Yu HS. The role of domestic tap water in Acanthamoeba contamination in contact lens storage cases in Korea. Korean J Parasitol. 2005;43:47.

92. Watanabe R, Ishibashi Y, Hommura S, Ishii K. Acanthamoeba isolation from contact lens solution of contact lens wearers without keratitis. Nippon Ganka Gakkai Zasshi. 1994;98:477-80.

93. Seal D, Kirkness C, Bennett H, Peterson M. Acanthamoeba keratitis in Scotland: risk factors for contact lens wearers. Cont Lens Anterior Eye. 1999;22:58-68.

94. Khor W-B, Prajna VN, Garg P, Mehta JS, Xie L, Liu Z, et al. The Asia Cornea Society Infectious Keratitis Study: A prospective multicenter study of infectious keratitis. Asia. Am J Ophthalmol. 2018;195;161-170. 